\title{
РЕАЛІЗАЦІЯ ДЕРЖАВНОЇ ПОЛІТИКИ У СФЕРІ ЗАБЕЗПЕЧЕННЯ ЕКОНОМІЧНОЇ БЕЗПЕКИ ДЕРЖАВИ ОКРЕМИМИ ВИЩИМИ ОРГАНАМИ ДЕРЖАВНОЇ ВЛАДИ
}

Кошиков Д. $О$.

Meта статmі полягає у дослідженні змісту та особливостей діяльності вищих органів державної влади як окре мої групи суб'єктів реалізації державної політики у сфері забезпечення економічної безпеки держави шляхом окреслення їх компетенції. У cmammi визначено низку вищих органів державної влади, які реалізують державну політику в сфері забезпечення економічної безпеки держави, серед них Верховна Рада України, Кабінет міністрів України, Президент України та суди. В результаті систематизації, узагальнення та аналізу повноважень вказаних органів, а також визначення їх компетенції автором було виділено особливості діяльності вищих органів державної влади як суб'єктів реалізації державної політики у сфері забезпечення економічної безпеки держави.

Визначено, що діяльність кожного з вищих органів державної влади є персоніфікованою. Вона обумовлюється правовим статусом, аїі межі визначаються завданнями та компетенцією; здійснюється в різних напрямах, які втілюються паралельно, доповнюють один одного та в сукупності дозволяють забезпечувати втілення державної політики в сфері забезпечення економічної безпеки держави. 3'ясовано, що компетенція вищих органів державної влади в межах діяльності, пов'язаної із забезпеченням економічної безпеки держави, здебільшого закріплюється в законодавчих, а не підзаконних актах, що свідчить про усталеність і стабільність повноважень відповідних органів у зазначеній сфері.

Наголошено, що специфіка суб'єктного складу вищих органів державної влади як суб'єктів забезпечення економічної безпеки обумовлює унікальне поєднання сфер їх діяльності, яке полягає не лише в формуванні державної політики, а і в організації їі реалізації та відправлення правосуддя судами.

Зроблено висновок, що більшість із вищих органів державної влади формують і реалізують державну політику в сфері забезпечення економічної безпеки шляхом здійснення організаційних та управлінських заходів, а також правового забезпечення, в той час коли конкретні дії, здатні вплинути на рівень економічної безпеки країни, здебільшого здійснюються на місцевому та локальному рівнях.

Ключові слова: економічна безпека, державна політика, вищі органи державної влади, Верховна Рада України, Кабінет Міністрів України, Президент України, суди, компетенція, повноваження.

Цель статьи заключается в исследовании содержания и особенностей деятельности высших органов государственной власти как отдельной группы субъектов реализации государственной политики в сфере обеспечения экономической безопасности государства путем определения их компетенции. Так, в статье определен ряд высших органов государственной власти, реализующих государственную политику в сфере обеспечения экономической безопасности государства, среди них Верховная Рада Украины, Кабинет министров Украины, Президент Украины и суды. В результате систематизации, обобщения и анализа полномочий указанных органов, а также определения их компетенции автором были выделены особенности деятельности высших органов государственной власти как субъектов реализации государственной политики в сфере обеспечения экономической безопасности государства.

Oпределено, что деятельность каждого из высших органов государственной власти является персонифицированной, она обусловливается правовым статусом, а ее границы определяются задачами и компетенцией; осуществляется в различных направлениях, которые воплощаются параллельно, дополняют друг друга и в совокупности позволяют обеспечивать внедрение государственной политики в сфере обеспечение экономической безопасности государства.

Выяснено, что компетенция высших органов государственной власти в рамках деятельности, связанной с обеспечением экономической безопасности государства, обычно закрепляется в законодательных, а не подзаконных актах, свидетельствует об устойчивости и стабильности полномочий соответствующих органов в указанной сфере. Отмечено, что специфика субъектного состава высших органов государственной власти как субъектов обеспечения экономической безопасности обусловливает уникальное сочетание сфер их деятельности, которая заключается не только в формировании государственной политики, а и в организации реализации и правосудия судами.

Сделан вывод, что большинство из высших органов государственной власти формируют и реализуют государственную политику в сфере обеспечения экономической безопасности путем осуществления организационных и управленческих мероприятий, а также правового обеспечения, в то время как конкретные действия, способные повлиять на уровень экономической безопасности страны, обычно осуществляются на местном и локальном уровнях.

Ключевые слова: экономическая безопасность, государственная политика, высшие органы государственной власти, Верховная Рада Украины, Кабинет Министров Украины, Президент Украины, суды, компетенция, полномочия.

The purpose of the article is to investigate the content and peculiarities of the activity of higher bodies of state power, as a separate group of subjects of realization of state policy in the sphere of economic security of the state, by defining their competence. Thus, the article identifies a number of higher bodies of state power implementing state policy in the sphere of economic security of the state, among them The Verkhovna Rada of Ukraine, the Cabinet of Ministers of Ukraine, the President of Ukraine and the courts. As a result of the systematization, generalization and analysis of the powers of the aforementioned bodies, as well as the determination of their competence, the author has highlighted the peculiarities of the activity of the higher bodies of state power as subjects of realization of the state policy in the sphere of economic security of the state. 
It is determined that the activity of each of the higher bodies of state power is personified, it is determined by the legal status, and its boundaries are determined by tasks and competence, so it is carried out in different directions, which are implemented in parallel, complement each other, and together allow to ensure the implementation of state policy in the sphere ensuring the economic security of the state.

It has been found out that the competence of the higher bodies of state power in the framework of activities related to ensuring the economic security of the state is usually enshrined in legislation, rather than by-laws, which testifies to the established and stable powers of the relevant authorities in the said field. It is emphasized that the specificity of the subjective composition of the higher bodies of state power as subjects of ensuring economic security determines a unique combination of spheres of their activity, which consists not only in the formation of state policy, but also in the organization of its implementation and the administration of justice.

It is concluded that most of the higher bodies of state power formulate and implement state policy in the sphere of economic security through the implementation of organizational and management measures, as well as legal support, while specific actions that capable of influencing the level of economic security of the country are usually implemented at local and local levels.

Key words: economic security, state policy, supreme bodies of state power, Verkhovna Rada of Ukraine, Cabinet of Ministers of Ukraine, President of Ukraine, courts, competence, powers.

Постановка проблеми та іï актуальність. Розбудова економічної сфери та реалізація систематичної державної політики потребує здійснення комплексних скерованих дій як на загальнодержавному, так i на регіональному рівнях, які в тому числі повинні бути спрямовані на стабілізацію економічної ситуації в країні, захист національної економіки та її розвиток. Зазначене $\epsilon$ підтвердженням того, що економічна політика держави формується та впроваджується суб'єктами на різних ступенях ієрархії: концептуальні ідеї опрацьовуються та знаходять своє нормативне закріплення на рівні вищих органів державної влади, отримують деталізацію та втілюються в формі конкретних заходів, що запроваджуються на рівні регіонів, міст, локальних утворень.

Види, форми, напрями та безпосередньо зміст такої діяльності в кожному конкретному випадку залежатиме від органу та рівня, на якому він знаходиться в системі органів державної влади, оскільки перед кожним із них ставляться власні унікальні завдання, що унеможливлює дублювання повноважень у сфері реалізації державної економічної політики. Лише досягнення спільних цілей, спрямованих на забезпечення економічної безпеки держави, визначених для всіх суб'єктів (вищих i центральних органів державної влади, органів місцевого самоврядування та громадянських інституцій) призведе до підвищення економічного рівня як всередині країни, так і укріпить їі позиції на міжнародній арені, світовому ринку.

Успіх і дієвість реалізації економічної політики держави можна представити як складний багатоелементний механізм, злагоджене функціонування якого залежить від усієї сукупності цілеспрямованих дій суб'єктів, кожний із яких провадить власну специфічну діяльність, наділений певною компетенцією, від чого відповідно прямо або опосередковано залежить вплив формування рівня безпеки національної економіки.

3'ясування діяльності суб'єктів, які реалізують державну політику в сфері забезпечення економічної безпеки держави, має прикладне значення, оскільки повинно бути враховане при виробленні планів реалізації такої політики в частині визначення компетенції кожного суб'єкта в певних напрямах, повинні бути взятими до уваги і особливості діяльності кожного з них. Це в свою чергу дозволить раціонально розподілити завдання, передбачені планом або стратегією забезпечення економічної безпеки держави, та раціонально розподілити їх між множинністю компетентних суб'єктів.

Аналіз останніх досліджень і публікацій. Правовий статус, роль і повноваження вищих органів державної влади, наприклад Парламенту чи Уряду, в сфері реалізації загальної державної політики досліджувалися вченими у різних галузях юриспруденції, зокрема 3.С. Гладуном [1], О.В. Лопушанською [2], Р.С. Мартинюком [3; 4], Р.М. Фрідманським [5], Ю.Ю. Чуприною [6]. Однак поза увагою сучасної науки залишилося складне і достатньо важливе питання реалізації вищими органами державної влади державної політики в сфері забезпечення економічної безпеки держави. Лише в деяких дослідженнях, наприклад С.І. Лекаря [7], опосередковано було встановлено роль окремих органів державної влади як суб'єктів забезпечення економічної безпеки.

Мета статті полягає у дослідженні змісту та особливостей діяльності вищих органів державної влади (на прикладі Верховної Ради України (далі - ВР України), Кабінету Міністрів України (далі - КМ України), Президента України та системи судів) як окремої групи суб'єктів реалізації державної політики у сфері забезпечення економічної безпеки держави шляхом окреслення їх компетенції.

Виклад основного матеріалу. Складником системи суб'єктів реалізації державної політики у сфері забезпечення економічної безпеки держави $\epsilon$ вищі органи державної влади, серед яких ВР України, Президент України, КМ України, суди, а також інші органи. Тому автор пропонує перейти безпосередньо до з'ясування особливостей діяльності перелічених вищих органів державної влади, які реалізують державну політику в сфері забезпечення економічної безпеки держави.

ВР України має монопольне право на прийняття законодавчих актів, що прямо встановлено в ст. 75 Основного Закону держави, тому цей суб'єкт є єдиним законодавчим органом із досить широким колом повноважень, зокрема в правотворчій діяльності, внаслідок реалізації яких Парламент впливає на стан економічної безпеки держави та іï забезпечення, здійснюючи власну діяльність у межах наданих законом повноважень.

Аналіз повноважень ВР України, закріплених у ст. 85 Конституції України, дозволяє дійти висновку, що вони стосується здійснення державної політики у сфері забезпечення економічної безпеки держави. Так, парламент приймає різноманітні законодавчі акти, в тому числі ті, що регулюють економічну сферу; схвалює Програми діяльності КМ України [8] та затверджує державні програми економічного розвитку, де безпосередньо відображається і безпековий аспект, без якого прогрес економічного сектору $\epsilon$ неможливим; приймає остаточне рішення та призначає на посади міністрів і голів Антимонопольного комітету України та Національного банку України, діяльність яких прямо пов'язана із забезпеченням економічної безпеки держави; здійснює контроль за роботою міністерств; при- 


\section{Економічна безпека держави:}

теорія і практика

ймає рішення про одержання позапланових фінансових позик державою [9]. ВР України безпосередньо не бере участі в реалізації державної політики в сфері забезпечення економічної безпеки держави, а лише забезпечує правову основу іï здійснення, визначає курс і пріоритетні напрями. Опосередковано від Парламенту залежить якість таких дій, оскільки саме цей орган приймає стратегічно важливі, зокрема кадрові, рішення щодо призначення суб'єктів втілення вказаної політики.

Президент України як гарант Конституції повинен забезпечувати незалежність держави та національну безпеку (п. 1 ч. 1 ст. 106 Конституції України), складником якої $\epsilon$ економічна безпека. В межах своїх повноважень Глава держави представляє інтереси країни та укладає міжнародні договори від імені держави, зміст яких може позитивно чи негативно позначитись на стані економічної безпеки, а також підписує законодавчі акти, прийняті ВР України, має право вето щодо них. Він може впливати на формування правових і організаційних засад реалізації державної політики у сфері забезпечення економічної безпеки держави, визначаючи іï загальний курс. Окрім того, є главою Ради національної безпеки і оборони України, безпосереднє завдання якої - забезпечення економічної безпеки та підтримання іï стабільного стану на рівні, достатньому для функціонування всіх соціальних сфер, а також може створювати допоміжні чи дорадчі органи.

Діяльність КМ України як суб'єктів реалізації державної політики у сфері забезпечення економічної безпеки держави окреслено в ст. 116 Конституції України. Будучи вищим органом державної виконавчої влади, його діяльність пов'язана із організацією та функціонуванням усіх суспільно важливих сфер (економічної, соціальної, культурної, правоохоронної тощо). Уряд забезпечує економічну самостійність держави, такий стан економічного сектору, який спроможний виробляти необхідні блага (товари) в достатній кількості для того, щоб забезпечити задоволення мінімальних потреб громадян. Адже за умов настання чи імовірності настання конкретної загрози, яка впливає на світовий і національний ринки, виробництво, промисловість, господарська діяльність не можуть здійснюватися на достатньому рівні.

КМ України є основним суб'єктом реалізації державної політики, в тому числі в сфері забезпечення економічної безпеки держави, а також суміжних сфеpax. Для цього Уряд «розробляє і здійснює загальнодержавні програми економічного, науково-технічного, соціального і культурного розвитку України; забезпечує рівні умови розвитку всіх форм власності; здійснює управління об'єктами державної власності відповідно до закону; розробляє проект закону про Державний бюджет України і забезпечує виконання затвердженого Верховною Радою України Державного бюджету України, подає Верховній Раді України звіт про його виконання» [9]. КМ України відповідно до курсу, визначеного Главою держави, утворює, реорганізовує, ліквідує та координує роботу відомств і міністерств, зокрема Міністерства розвитку економіки, торгівлі та сільського господарства України.

Більш детально повноваження КМ України в економічній сфері розкрито в ч. 1 ст. 20 Закону України «Про Кабінет Міністрів України». Здебільшого всі вони пов'язані зі здійсненням державної економічної політики, виконанням конкретних економічних програм (цільо- вих програм і програм перебудови окремих економічних галузей), контролем за роботою інших суб'єктів у зазначеній сфері. Одночасно необхідно вказати на те, що нормами вказаної статті регламентовано і конкретні заходи, які реалізує Уряд у межах державної політики в сфері забезпечення економічної безпеки держави, зокрема сприяння розвитку підприємництва; «здійснення державної регуляторної політики у сфері господарської діяльності; захист і підтримка національного товаровиробника; захист прав споживачів і підвищення якості їх життя; організація державного страхування» [10] та обслуговування державного замовлення.

Економічна сфера $\epsilon$ багатоелементним утворенням, яке не обмежується лише виробництвом товарів або регулюванням торгівлі, тому надзвичайно важливим для забезпечення економічної безпеки також $\epsilon$ й інші напрями діяльності КМ України: втілення державної політики в сферах агропромислового комплексу, ціноутворення, зовнішньої економіки, фінансів, податків і трудових відносин. Саме цей орган акумулює і узагальнює основні засади забезпечення загальнодержавної, економічної політики, проектуючи організаційну, правову та матеріально-технічну основу для реалізації такої політики відповідно до тенденцій розвитку, визначених Президентом України, та подає їх на затвердження ВР України.

Згідно з ч. 1 ст. 124 Основного Закону держави правосуддя в Україні здійснюється виключно судами [9]. Схожа норма міститься в ст. 2 Закону України «Про судоустрій і статус суддів»: «Суд, здійснюючи правосуддя на засадах верховенства права, забезпечує кожному право на справедливий суд та повагу до інших прав і свобод, гарантованих Конституцією і законами України, а також міжнародними договорами, згода на обов'язковість яких надана Верховною Радою України» [11].

Сутність правосуддя полягає в тому, що суд як неупереджений об'єктивний арбітр приймає рішення по суті вчинення тих чи інших правопорушень, значну частину з яких складають правопорушення в економічній сфері. Наявність останніх апріорі справляє деструктивний вплив на економічну сферу, а тому $є$ однією з найочевидніших загроз економічній безпеці держави. Такі правопорушення закріплені в КК України та КУпАП.

Особлива частина КК України консолідує злочини, скоєння яких прямо чи опосередковано впливає на зниження рівня економічної безпеки держави, здійснюючи дестабілізуючий вплив на національну економіку. Вони закріплені в таких розділах КК України: «Злочини проти основ національної безпеки України»; «Злочини проти волі, честі та гідності особи» (наприклад, торгівля людьми (ст. 149); експлуатація дітей (ст. 150); використання малолітньої дитини для заняття жебрацтвом (ст. 150-1); «Злочини проти власності»; «Злочини у сфері господарської діяльності»; «Злочини проти громадської безпеки» (вчинення терористичного акту (ст. 258) або фінансування тероризму (ст. 258-5); «Злочини проти безпеки виробництва»; «Злочини у сфері охорони державної таємниці, недоторканності державних кордонів, забезпечення призову та мобілізації»; «Злочини проти авторитету органів державної влади, органів місцевого самоврядування, об'єднань громадян і злочини проти журналістів» (заволодіння документами, штампами, печатками (ст. 357), їх підроблення (ст. 358); незаконні придбання, збут або використання спеціальних техніч- 
них засобів отримання інформації (ст. 359); «Злочини у сфері використання електронно-обчислювальних машин (комп'ютерів), систем і комп'ютерних мереж і мереж електрозв'язку»; «Злочини у сфері службової діяльності та професійної діяльності, пов'язаної з наданням публічних послуг» [12].

Не менш небезпечними для економічної безпеки держави $є$ вчинення адміністративних правопорушень, які, на відміну від злочинів, не характеризуються суспільною небезпекою, проте можуть призвести до вчинення перших або ж поступово протягом тривалого періоду здатні руйнувати систему економічної безпеки. В окремі розділи КУпАП об'єднані адміністративні правопорушення, які посягають на сферу промисловості, будівництво, використання паливно-енергетичних ресурсів (Глава 8), а також транспортну сферу; галузі шляхового господарства і зв'язку (Глава 10), торгівлі, громадського харчування, сферу послуг, фінансів і підприємницької діяльності (Глава 12), стандартизації, якості продукції, метрології та технічного регулювання (Глава 13); встановлений порядок управління (Глава 15) [13].

Рішення по цих справах у разі вчинення злочинів або адміністративних правопорушень приймаються місцевими, апеляційними, вищими спеціалізованими судами та Верховним Судом. У такому контексті автор поділяє думку С.І. Лекаря з приводу того, що «суди загальної юрисдикції здійснюють судочинство у справах про злочини, які завдають шкоди економічній безпеці України; забезпечують судовий захист суб' єктів економічної безпеки, чиї права були порушені у зв'язку з діяльністю із забезпечення економічної безпеки» [7, с. 80].

Висновки. Проведена загальна характеристика діяльності вищих органів державної влади, пов'язана з реалізацією державної політики у сфері забезпечення економічної безпеки держави, дозволяє дійти висновку про те, що кожний із таких органів втілює специфічні, відмінні одне від одного заходи, що лише в сукупності спроможні будувати та розвивати стабільну економічну сферу, яка зможе «протистояти» внутрішнім і зовнішнім загрозам. Об'єднані єдиною метою вищі органи державної влади як самостійно, так і взаємодіючи між собою та іншими органами здійснюють діяльність у рамках державної політики в сфері забезпечення економічної безпеки держави, яка характеризуються такими особливостями:

1) діяльність кожного з вищих органів державної влади $\epsilon$ персоніфікованою, обумовлюється правовим статусом, а їі межі визначаються завданнями та компетенцією, здійснюється в різних напрямах, які втілюються паралельно, доповнюють один одного та в сукупності дозволяють забезпечувати втілення державної політики в сфері забезпечення економічної безпеки держави;

2) компетенція вищих органів державної влади в межах діяльності, пов'язаної із забезпечення економічної безпеки держави, здебільшого закріплюється в законодавчих, а не підзаконних актах, що свідчить про усталеність і стабільність повноважень відповідних органів у зазначеній сфері;

3) специфіка суб'єктного складу вищих органів державної влади як суб'єктів забезпечення економічної безпеки обумовлює унікальне поєднання сфер їх діяльності, яка полягає не лише у формуванні державної політики (ВР України, Президент України), а і в організації іiї реалізації (КМ України) та відправлення право-

\section{суддя судами;}

4) більшість із вищих органів державної влади (ВР України, Президент України, КМ України) формують і реалізують державну політику в сфері забезпечення економічної безпеки шляхом здійснення організаційних та управлінських заходів, а також правового забезпечення, в той час коли конкретні дії, здатні вплинути на рівень економічної безпеки країни, здебільшого здійснюються на місцевому та локальному рівнях;

5) наявність специфічного виду дуальності - адміністративно-юрисдикційної, яка полягає не лише у розгляді справ про адміністративні правопорушення судами, а і в їх порушенні та попередньому з'ясуванні обставин як одного з напрямів забезпечення економічної безпеки держави деяких вищих органів держаної влади, що обумовлено специфічною загрозливістю окремих адміністративних деліктів економічним правам та інтересам окремих громадян, суспільства та держави;

6) в межах управлінської діяльності, яка $\epsilon$ складником процесу реалізації державної політики в сфері забезпечення економічної безпеки, окремими вищими органами державної влади, зокрема ВР України, розв'язуються важливі кадрові питання, наприклад призначення на посади міністрів і голів Антимонопольного комітету України та Національного банку України;

7) діяльність щодо реалізації державної політики у сфері забезпечення економічної безпеки держави включає не лише спеціалізовані напрямки економічного характеру, а пов'язана також і з загальносоціальними аспектами розвитку суспільства (організацією дозвілля населення, побутового, культурного життя громадян, розвитком індивідуальності кожного громадянина, забезпеченням достойними умовами праці).

Вказані особливості діяльності вищих органів державної влади не зможуть об'єктивно розкрити сутність і специфіку процесу реалізації державної політики в сфері забезпечення економічної безпеки держави, оскільки така діяльність уособлює лише частину заходів, спрямованих на забезпечення стабільного економічного розвитку та захисту національної економіки. Принаймні виходячи з того, що до таких вищих органів державної влади в контексті забезпечення економічної безпеки держави та реалізації державної політики доцільно прирівняти органи зі специфічним статусом і винятковою компетенцією - Раду національної безпеки і оборони, Антимонопольний комітет і Національний банк України. Діяльність таких органів відіграє важливу роль у забезпеченні економічної безпеки держави, а тому потребує досліджень у межах подальших наукових пошуків.

\section{Література}

1. Гладун 3.С. Державна політика охорони здоров'я в Україні (адміністративно-правові проблеми формування і реалізаціі) : монографія. Тернопіль : «Економічна думка», 2005. 460 c.

2. Лопушанська О.В. Верховна Рада України як суб'єкт адміністративно-правового регулювання мовної політики. Науковий вісник Ужгородського національного університету. Серія: Право. 2015. Вип. 35 (1.2). С. 126-129.

3. Мартинюк Р.С. Кабінет Міністрів України в системі стримувань і противаг на сучасному етапі. Юридична Україна. 2008. № 7. С. 28-32.

4. Мартинюк Р.С. Президент України в системі стримувань і противаг на сучасному етапі. Підприємництво, господарство і право. 2008. № 8. С. 28-31. 


\section{Економічна безпека держави: теорія і практика}

5. Фрідманський Р.М. Функціональне призначення Кабінету Міністрів України. Науковий вісник Ужгородського національного університету. Серія: Право. 2013. Вип. 22. Т. 1. Ч. 1. С. 119-121.

6. Чуприна Ю.Ю. Місце судової гілки влади в системі державної влади України. Державне будівництво. 2010. № 1. URL: http://nbuv.gov.ua/UJRN/DeBu_2010_1_37 (дата звернення: 27.10.2019).

7. Лекарь С.І. Економічна безпека держави та суб'єк-

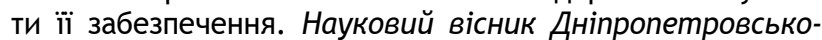
го державного університету внутрішніх справ. 2012. № 2. C. 75-83.

8. Про Програму діяльності Кабінету Міністрів України : Постанова Верховної ради України від 04.10.2019 № 188-IX. Офіційний вісник України. 2019. № 82. Ст. 2792.

9. Конституція України від 28.06.1996 № 254к/96-ВР. Відомості Верховної Ради України. 1996. № 30. СТ. 141.
10. Про Кабінет Міністрів України : Закон України від 27.02.2014 № 794-VII. Відомості Верховної Ради України. 2014. № 13. СТ. 222.

11. Про судоустрій і статус суддів : Закон України від 02.06.2016 № 1402-VIII. Відомості Верховної Ради України. 2016. № 31. Ст. 545.

12. Кримінальний кодекс України від 05.04.2001 № 2341III. Відомості Верховної Ради України. 2001. № 25-26. Ст. 131.

13. Кодекс України про адміністративні правопорушення від 07.12.1984 № 8073-Х. Відомості Верховної Ради Української РСР. 1984. Додаток до № 51. Ст. 1122.

Кошиков Д. О., кандидат юридичних наук, старший викладач кафедри поліцейської діяльності та публічного адміністрування Харківського національного університету внутрішніх справ 